\title{
Wyznaczniki człowieczeństwa i płynące stąd powinności wobec Innego
}

\author{
Maria Szyszkowska \\ Uniwersytet Warszawski \\ m.szyszkowska@wpia.uw.edu.pl \\ ORCID: https://orcid.org/0000-0003-0125-2616
}

Podjęty tu problem wymaga sformułowania dwóch uwag wstępnych. Po pierwsze, znaczenie człowieka nie zawiera się $w$ tym, że jest zdolny do pracy zarobkowej, Nie zawiera się też $\mathrm{w}$ inteligencji, a zwłaszcza $\mathrm{w}$ zdolności przystosowywania się do przeważających poglądów i obyczajów. Zgodnie z teorią dezintegracji pozytywnej najbardziej cenne są osoby pozytywnie nieprzystosowane do społeczeństwa. Są to osoby twórcze, poszukujące własnej drogi i nieulegające presji większości, którą tworzą jednostki przeciętne. Zdaniem twórcy tej teorii Kazmierza Dąbrowskiego, psychiatry i filozofa, negatywne nieprzystosowanie zachodzi jedynie $\mathrm{w}$ trzech następujących przypadkach: alkoholizmu, narkomanii i lekomani oraz drogi przestępstw. Po drugie, rozum osób sprawnych intelektualnie ulega manipulacji. Jest ona szczególnie wzmożona w XXI w. z powodu wpływu na nas kultury obrazkowej. Wszechwładne media sugerują wartości we wszystkich dziedzinach życia wraz ze wzorami postępowania.

Od początku powstania filozofii uwagę myślicieli absorbowało pytanie: co stanowi wyznacznik człowieczeństwa? W starożytności przyjęto jako oczywiste, że tylko człowiek jest wyposażony w rozum i że jest on właściwością zespoloną z naszą naturą. W średniowieczu, pod wpływem chrześcijaństwa, uznano, że znamieniem człowieczeństwa jest nieśmiertelna dusza. Stąd do dziś uznaje się jako uprawnione w kulturze euroamerykańskiej panowanie człowieka nad innymi istotami żywymi. Pod wpływem neokantyzmu w drugiej połowie XIX w. uznano, że tworzenie kultury jest znamieniem człowieka, cechą odróżniającą nas od innych istot żywych. Ani zwierzęta, ani rośliny nie są zdolne do tworzenia świata kultury. $Z$ kolei na przełomie XX i XXI w. z niepokojem określono człowieka jako jedyną istotę śmiecącą. Nikt poza nami, ludźmi, nie niszczy środowiska, w którym żyje. 
Nie mniejsze zainteresowanie wywołuje od czasów starożytności pytanie, który czynnik dominuje w życiu człowieka, a zwłaszcza w procesie poznawania świata. Racjonaliści uznali, że rozum jest źródłem wiedzy prawdziwej. Empiryści wskazali na zmysły, a więc inaczej na doświadczenie jako na źródło wiedzy prawdziwej. Irracjonaliści twierdzą, że źródłem wiedzy prawdziwej jest intuicja. Irracjonalizm, dodam na marginesie, nie należy w kulturze europejskiej do prądu dominującego. Według filozofii chrześcijańskiej wiara religijna jest źródłem wiedzy prawdziwej.

Racjonalizm sokratejsko-kartezjańsko-heglowski zdominował kulturę europejską. Dopiero w XX w. zostało zakwestionowane pojęcie „czystego myślenia”, a więc niezależnego od doznań i wyobraźni. W połowie XX w. ustalono wszechobecność uczuć w psychice człowieka. Leżą one u podstaw nawet $\mathrm{z}$ pozoru czysto intelektualnych dociekań. Zostało ustalone, że nie ma stanu psychicznego wolnego od uczuć. Ale nie wyciągnięto z tego należytych wniosków. Mianowicie edukacja szkolna i wyższa nie pomaga w rozwoju sfery uczuć, w podnoszeniu ich na wyższy poziom. Nastawiona jest na kształtowanie sfery intelektualnej. Nie pomaga także w rozwoju wyobraźni i zachowaniu wrażliwości - z jaką przyszło się na świat przez całe życie.

Należy tu mocno podkreślić, że osoby niepełnosprawne intelektualnie, bywa, odznaczają się ponadprzeciętną uczuciowością. A o wartości człowieka decyduje przede wszystkim wysoki poziom rozwoju uczuć, duża wrażliwość oraz rozwinięta wyobraźnia. Wszak psychopaci, którzy stanowią zagrożenie w życiu rodzinnym i społeczeństwa, odznaczają się z reguły ponadprzeciętną inteligencją i są wśród nich osoby wysoko wykształcone. Psychopata to człowiek, którego rozum pozostaje na usługach popędów. Najsilniejsze spośród nich to dążenie do władzy i pieniędzy. Zdaniem Kazimierza Dąbrowskiego największą liczbę psychopatów spotyka się w grupie polityków poszczególnych państw.

Tym, co narusza człowieczeństwo, jest przede wszystkim konformizm i oportunizm, a więc wypieranie się własnego światopoglądu. Następuje to bądź z lęku przed brakiem aprobaty, bądź ze względu na chęć osiągnięcia sukcesu i zrobienia kariery. Wypieranie się autentycznych przekonań światopoglądowych degraduje człowieka. W tym zestawieniu należy cenić wyżej niż konformistów i oportunistów osoby niesprawne intelektualnie. Nie ulegają one pokusom, by zdradzać własne „ja”. Zmianie powinno podlegać otoczenie osób niesprawnych intelektualnie.

Osoby niesprawne intelektualnie wymagają opieki państwa, bowiem nie są zdolne same dawać sobie radę. Są pozbawione sprytu życiowego. Ta niesamowystarczalność pozostaje w sprzeczności z funkcjonującą w XXI w. w kulturze euroamerykańskiej neoliberalną koncepcją państwa. Otóż przyjęło się obecnie jako oczywiste, że państwo ma zajmować się jedynie zbieraniem podatków, polityką międzynarodową oraz wojskiem. Krytykowana jest ostro znamienna dla liberali- 
Wyznaczniki człowieczeństwa i płynące stąd powinności wobec Innego

zmu ekonomicznego koncepcja państwa opiekuńczego. W XIX w., a więc w epoce kapitalizmu, John S. Mill rozwinął teorię państwa przychodzącego z pomocą obywatelom. Co więcej, państwa troszczącego się także o to, by zwierzęta nie cierpiały z powodu możliwego sadyzmu człowieka.

Wynika stąd wyraźnie, że sławiony w naszych czasach postęp dotyczy rozkwitu cywilizacji, ale wiąże się z regresem relacji państwo-obywatel. Dodam, że regres dotyczy też poddawania w wątpliwość wartości ideałów, które powinny wyznaczać istnienie człowieka.

Nie ma wątpliwości, że osoby niepełnosprawne intelektualnie wymagają szczególnych rozwiązań w skali państwa. Oszczędności finansowe leżące u podstaw rozmaitych przepisów prawnych nie powinny być czynnikiem dominującym. Otóż należy wrócić do koncepcji szkół specjalnych dla osób z niedorozwojem intelektualnym. Ich likwidacja zmniejsza wydatkowanie pieniędzy z budżetu, ale nie służy przygotowaniu tych osób do życia. W szkołach specjalnych zatrudnieni byli i są - jeśli nie zostały zlikwidowane - specjaliści. Oni jedynie mogą pomóc skutecznie tym, którzy nie dają sobie sami rady. Należy podkreślić, że Polska słynęła z wysokiego poziomu tych likwidowanych szkół specjalnych.

Szkoły integracyjne, obecnie zalecane, pozbawiają uczniów niepełnosprawnych intelektualnie fachowej pomocy. A ponadto wzmagają w nich poczucie dysproporcji między sobą a kolegami pełnosprawnymi intelektualnie i fizycznie. Jest też oczywiste, że uwaga nauczycieli koncentruje się bardziej na uczniach intelektualnie wyżej stojących, ze szkodą dla pozostałych. Ponadto poziom nauczania w szkołach integracyjnych jest obniżony, bo inaczej nie będzie możliwe do przyswojenia przez wszystkich uczniów. Trzeba też podkreślić, że uczniowie pełnosprawni intelektualnie oraz fizycznie niepotrzebnie stykają się z kolegami pozbawionymi tych właściwości. We wrażliwych uczniach może to wywoływać bardzo mocne przykre doznania i refleksje, na które powinien być czas w życiu człowieka dorosłego.

Wobec osób, które są niepełnosprawne intelektualnie oraz fizycznie, płyną powinności. Wszak życie w społeczeństwie i w państwie nakłada zobowiązania nie tylko wobec siebie i własnej rodziny, ale także wobec innych nieznanych sobie osób. Zasada miłości bliźniego przez wiele wieków nie została urzeczywistniona. Powrócić więc należy do zasady braterstwa wszystkich ludzi, sformułowanej w starożytności przez stoików. Jeżeli odstąpimy od szczególnych powinności wobec Innego, to zarazem przyznamy niejako milcząco rację anarchistom, którzy w imię wolności jednostki, wolnej także od obowiązków wobec innych, podważali wartość instytucji państwa.

Ażeby świadomość społeczeństwa nasycić poczuciem powinności wobec Innego, należy odejść od pojmowania człowieka jako kapitału ludzkiego czy zasobu ludzkiego. Dodam, że to wadliwe pojmowanie człowieka, obecnie funkcjonując, 
sprawia, że pustosłowiem stają się stwierdzenia o godności człowieka, jak również różnorodne deklaracje praw człowieka.

Należy wyjaśniać, że człowiek zdrowy i pełnosprawny intelektualnie, to znaczy zdolny do rozwoju, do przekształceń trwających przez cały okres istnienia, dąży w kierunku ideału indywidualnego oraz społecznego. Przytaczam ten sposób rozumienia zdrowego człowieka za Kazimierzem Dąbrowskim, który słusznie kwestionuje rozmaite funkcjonujące koncepcje zdrowego człowieka. Z przytoczonego punktu widzenia wiele osób uznawanych potocznie za zdrowe jest chorych.

Trzeba tu dodać, że funkcjonująca u nas świętość życia, w tym także embrionów, pozostaje w sprzeczności z aprobatą dla tzw. słusznych wojen. Wracają z nich osoby niepełnosprawne fizycznie i z reguły - psychicznie. Sytuacje graniczne, jakimi jest zabijanie człowieka w czasie wojny, obecnie często także ludności cywilnej, sprawiają, że takie przeżycia uniemożliwiają powrót do - nazwijmy to - normalnego życia. Jednakże ideały pacyfistyczne są nie tylko nieobecne, ale także krytykowane.

Osoby niepełnosprawne fizycznie oraz niepełnosprawne psychicznie tworzą grupy mniejszościowe. Nie są zdolne, by troszczyć się o własne potrzeby. Tymczasem prawne umocowanie lobbingu powoduje, że na pierwszy plan wysuwają się oczekiwania, a raczej interesy grup osób bogatych. Stać ich bowiem na opłacanie lobbystów.

Do grup określanych mianem Innego można też zaliczyć więźniów. Sprawą zasadniczą jest właściwy dobór osób pracujących z Innymi, w tym wypadku działań mających na celu przywrócenie byłych więźniów do życia w społeczeństwie. Pominę tu dyskusje i słuszny, moim zdaniem, pogląd profesora Andrzeja Bałandynowicza, iż kara izolacji powinna zostać jak najrychlej zlikwidowana na rzecz kar odbywanych pod kontrolą na wolności. Dopóki istnieje przestarzała instytucja zakładów karnych z wątpliwymi efektami resocjalizacji, dopóty powinno się uwzględnić słuszne postulaty płynące $z$ nauki, jaką jest higiena psychiczna. Twórca tej wiedzy teoretycznej i zarazem mającej praktyczne zastosowanie Kazimierz Dąbrowski domagał się zarówno w okresie międzywojennym, jak i w czasach PRL, by wychowawcy w więzieniach, sanitariusze w szpitalach, opiekunowie w domach dla ludzi sędziwych, pielęgniarze w zakładach psychiatrycznych i domach dla osób z niedorozwojem intelektualnym nie byli zatrudniani przypadkowo. Idzie mianowicie o to, by byli poddawani testom sprawdzającym ich poziom wrażliwości, rozwoju uczuć, zdolności do empatii. Niebezpieczeństwo zawiera się w tym, że te rodzaje prac wybierają często osoby psychopatyczne, a także o usposobieniu sadystycznym, pragnące dominować nad innymi.

Natrafiłam na czasopismo „Pracownik Więzienny” z 1922 r., w którym zostały sformułowane wskazania, a raczej nakazy dla polskich pracowników więzien- 
nych. Poza oczywistym nakazem trzeźwości i punktualności zostały sformułowane postulaty, które należałoby rozszerzyć na pielęgniarzy i opiekunów grup określanych mianem Inni. Poza wskazaniem uprzejmości funkcjonuje w tym wykazie nakaz bezwzględnej stanowczości i zarazem niezmąconej równowagi wewnętrznej. Sugeruje się, by pracując, myślało się wyłącznie o „zajmowanym posterunku”. Ta koncentracja na wykonywaniu powierzonych zadań w oczywisty sposób służy dobru podopiecznych. Wskazaniem o znaczeniu powszechnym jest następujące: „Zapomnij o błędach przeszłości, a staraj się o lepsze wyniki w przyszłości”. Cenne jest również wskazanie, by zachowywać pogodne usposobienie i uśmiechać się do każdego spotkanego „żywego stworzenia”, a więc tę życzliwość przenosić także na krąg zwierząt.

Poczucie zgodności własnego życia z autentycznie wyznawanymi poglądami na świat sprzyja ogromnie relacjom $z$ Innymi. Zaangażowanie w sprawy wspólne i świadomość tego, że jest się cząstką ludzkości, sprzyja wykonywaniu powierzonych obowiązków i rodzi prawidłowy stosunek do tych, którzy odstają od przeciętności.

Należy mieć wątpliwości co do pełni człowieczeństwa, ale tych, którzy kogoś dyskryminują. Cenny jest pogląd profesora Dąbrowskiego, że najbardziej wartościowymi jednostkami w społeczeństwie są psychonerwicowcy - z powodu wysokiego rozwoju uczuć i ponadprzeciętnej wrażliwości. Z tego kręgu osób wywodzą się twórcy rozmaitych dziedzin. Nieporozumieniem jest poskramianie nadmiernej spontaniczności i emocjonalności. Wątpliwym modelem człowieka jest ktoś wyrównany uczuciowo i poddający swoją sferę emocjonalną nakazom rozumu. Paradoks polega na tym, że często ci, którzy wychowują czy resocjalizują, sami powinni być socjalizowani.

Warto zaznaczyć, że w kształtowaniu każdego człowieka znaczącą rolę powinny odgrywać wartości immoralne, a więc inne niż dobro i zło. Moralizowanie jest mało skuteczne. Ponadto osób, które można by zaliczyć do typu religijnego, jest mało. Piszę o tym dlatego, że umoralnianie o charakterze religijnym przynosi stosunkowo mały efekt. Wpływa na zachowania i obyczaje, ale to nie znaczy, że przeobraża wewnętrznie.

Jak podkreśla Tadeusz Kotarbiński, jaźń ludzi dorosłych nie wygasa do ostatnich dni istnienia. Człowiek dorosły jest zdolny do wewnętrznych przekształceń, a podatność na to filozof ten uzasadnia nagromadzonymi doświadczeniami życiowymi. W tych przekształceniach pozytywną rolę odgrywa praca zgodna $\mathrm{z}$ zainteresowaniami Innego, oczywiście o ile jest do niej zdolny. Pozytywne znaczenie ma także kontakt ze sztuką oraz literaturą piękną.

Problem zawiera się w tym, że na ogół oczekuje się, by ludzie byli do siebie podobni. Zarówno jednostki wybitne, jak i osoby określane mianem Innego bywają 
negatywnie oceniane i nie znajdują oczekiwanego zrozumienia. Należy więc poszerzać horyzonty myślowe osób, które nie wymagają resocjalizacji, by z życzliwością i głęboką tolerancją odnosiły się do Innego. Utrudnia taki stosunek narastająca specjalizacja w edukacji i wyrugowanie filozofii z nauczania, bowiem w rezultacie wybitni specjaliści nie odznaczają się wystarczającą dozą mądrości, a tę czerpie się właśnie z filozofii.

Inni tworzą grupę społeczeństwa zepchniętą na margines życia w państwie. Dzieje się tak, mimo że żyjemy w epoce globalizmu, zgodnie z którą należy traktować każdego człowieka jako wartość najwyższą i zarazem cząstkę ludzkości. Nikt nie powinien podlegać restrykcjom światopoglądowym.

Inny to nie znaczy gorszy. Jeżeli ktoś ma podlegać krytyce, to ci, którzy wybierają postawy konformistyczne, posługując się wszak rozumem. Znaczenie człowieka nie zawiera się w tym, że jest zdolny do pracy zarobkowej, odznacza się wysokim ilorazem inteligencji i jest przystosowany do społeczeństwa. Osoby niesprawne intelektualnie o wysoko rozwiniętej sferze uczuć są bliższe pełni człowieczeństwa niż ci, którzy zajmują się głównie czerpaniem korzyści z działań publicznych, bądź ci, którzy kogoś dyskryminują, mimo że sprawnie funkcjonuje ich rozum.

\section{Bibliografia}

Dąbrowski K., Osobowość i jej kształtowanie poprzez dezyntegracje pozytywna, Warszawa 1975.

Demokratyczne ścieżki edukacji, red. M. Kamińska-Juckiewicz, L. Tomaszewska, Płock 2010.

Miejsce Innego we współczesnych naukach o wychowaniu, red. I. Chrzanowska, B. Jachmiczak, Poznań 2013.

Młode pokolenie, red. T. Sołtysiak, Bydgoszcz 2010.

Niezbędność filozofii, red. M. Szyszkowska, Białystok 2019.

Nowa jakość w edukacji?, red. J. Piekarski, Poznań 2013.

„Pracownik Więzienny” 1922.

Szyszkowska M., Negatywne przemiany w sferze wartości jako skutek rewolucji informacyjnej, [w:] Rewolucja informacyjna a kryzys intelektualny, red. J. Auleytner, J. Kleer, Warszawa 2005.

Szyszkowska M., Etyka, Białystok 2017.

Zdrowie psychiczne, red. K. Dąbrowski, Warszawa 1979. 